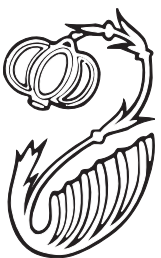

\title{
Translation, Migration, and \\ Communication in the Roman Empire: Three Aspects of Movement in History
}

\begin{abstract}
This paper isolates movement as a topic for analysis in Roman imperial history. Movement is regarded under three aspects: translation (of texts, practices, ideas), migration (of officials, merchants, students, etc.), and communication (i.e. the movement of written documents). Interrelationships among the three aspects of movement are identified and discussed, as are the shared impact of translation, migration, and communication on issues of cultural and social identity and political negotiation and control. The article argues that movement changes the role of the state as well as relations between individual and states, augments the use of writing in society, transforms identities, and gives impulse to internal and external regulations. The implications of movement are understood as both pragmatic and formal, altering relations to space and time and influencing ways of organizing and thinking. The author surveys current work in the field and identifies potential areas for future research. The paper draws heavily on both literary and documentary sources and discusses material from the late republic through late antiquity, paying particular attention to continuities and discontinuities between early and later periods of the Roman empire.
\end{abstract}

Moses Finley's definition of ancient societies as face-to-face societies has profoundly influenced Greek and Roman studies, in part by encouraging a static approach to them. This approach is not inaccurate, but it hides another and very specific aspect of the ancient Mediterranean world, namely movement. As instances of movement I consider here translation, communication, and migration: three forms of interaction between cultural areas, all involving the same

Editors' note: From time to time Classical Antiquity publishes an essay that offers a broad synthesis of recent and emerging work on an important topic in ancient studies. The present article, adapted from remarks Professor Moatti delivered at the University of Southern California in fall 2002, provides an overview of a number of projects she has sponsored on issues of mobility and migration in the ancient Mediterranean world.

The author wishes to thank Thomas Habinek for his help in the translation of this text and Sarah Blake and Elizabeth Ditmars for help with the preparation of the manuscript.

Classical Antiquity. Vol. 25, Issue 1, pp. 109-140. ISSN 0278-6656(p); 1067-8344 (e).

Copyright (C) 2006 by The Regents of the University of California. All rights reserved. Please direct all requests for permission to photocopy or reproduce article content through the University of California Press's Rights and Permissions website at www.ucpress.edu/journals/rights.htm. 
questions - of identity, of political and social control, and of the impact of writing in oral societies.

Every society experiences movement. But in the same way as some historians try to minimize change and discontinuity or to see them as categories of lesser interest than continuity, some also minimize movement: in this context, movement becomes "the stigma of spatial dislocation that it is the historian's task to remove from history." Of course, movement does not have the same importance everywhere, nor the same effects. But as has been established by the developments of physics since the sixteenth century, movement is a positive part of human experience, and not only a rupture of immobility, even if societies do not always recognize its importance. Being a structural component of human experience and the human mind, movement necessarily influences ways of thinking, relations of men to space, time, tradition, and the organization of societies. Moreover, like an anamorphosis, movement modifies the perception of things and of human relations. In that sense, it has to be studied as a specific historical object with specific laws and effects. My precise aim is to show how in Roman society translation changed the conception of culture, migration the definition of identity and social control, and communication the nature of politics. I also seek to understand the place the Romans gave to movement in culture and politics: for example, what was the link between mobility (in all its aspects) and thought?

These three forms of movement are not arbitrarily linked here. Translation, for example, was not only a cultural practice, but also a way of governing, one aspect of political communication between center and periphery in a bilingual empire. But translation was also linked to migration in other ways. The Letter of Aristeas, a document that was probably written at the beginning of the first century $\mathrm{BCE},{ }^{2}$ relates that when King Ptolemy II wanted the Bible to be translated into Greek, he asked the high priest of Jerusalem to send him translators. The story, whether true or not, shows that translation is first, and quite literally, a movement from one culture to another one: in this instance, from Jerusalem to Alexandria. We might say then that translation is a kind of travel; or at least that translations are always developed in periods and countries where physical contacts between different people are most important. Translation is a feature of cosmopolitanism and is linked to mobility and communication.

1. See the introduction to Foucault 1972.

2. The best edition is that of Pelletier 1962; see also Reggiani 1979, Charles 1963. 


\section{TRANSLATION}

Our aim is not to study translation from a philological point of view, but to propose an anthropological approach, in order to understand what is socially at stake in the act of translation-or in resistance to it. ${ }^{3}$

Translation may be regarded as a distinctive characteristic of Mediterranean societies. At the beginning of an essay on Moses, the Egyptologist Jan Assman discusses the suitability of these societies to translation. "Pagan societies," he writes, "have not only sought to construct their own identity but have also developed techniques of translation that favored interaction between cultures." According to Assman, polytheism was one of these techniques of translation: it allowed the assimilation of gods, their interpretatio, as the ancient Romans would have put it. It means also that in ancient pagan societies there was no place for cultural incompatibility. However, although all pagan societies practiced these techniques of translation, Roman society seems to present a special case.

First, we may say that the Romans brought the principle of translation to its fullest development: ${ }^{5}$ Latin literature was from its beginnings a translation not only from Greek to Latin (e.g. Livius Andronicus' translation of the Odyssey and the plays of Roman theater) but also from Latin to Greek. ${ }^{6}$ For example, historiography was at first and always written in Greek, even after Roman historians had decided to write in Latin or to translate Roman historical works from Greek to Latin. $^{7}$ And it was, as is well known, the same in philosophy and medicine. Thus, the Romans, who administered their empire in utraque lingua, ${ }^{8}$ thought it was culturally possible to speak in one language and write in another, ${ }^{9}$ to transmit culture in two languages ${ }^{10}$ and even to translate their own texts ${ }^{11}$-important ev-

3. In Rome, during the republic and early empire, many arguments were invoked against translation: that learned people could read Greek (Varro ap. Cic. Acad. 1.4); that the Latin language was too poor (Lucr. 1.139; Vitr. 5.4.1; on egestas latini sermonis see for example Fögen 2000); that some texts could not be translated, especially technical ones (Manilius Astron. 3.40-42: non omnia flecti possunt; Quint. Inst. 2.14.1; Gell. 16.8.1-5); that through translations, Greek expressions would lose their efficacy, for example in magic and in philosophy (cf. M. Aur. Med. 4.3.3). All these arguments deserve a close analysis.

4. Assman 1997: 19-20.

5. It is surprising that translation at Rome has not been very much studied. While there is discussion of individual authors (Cicero, Plautus, Boethius), general studies of the phenomenon are very few: Traina 1970; Courcelles 1969; Kaimio 1979; Traina 1989.

6. We might say that the Romans translated their Annales into Greek, as Josephus says that Manetho did with the sacred Egyptian annals (Ap. 1.14.73).

7. On the translation of Acilius' Annales see Liv. 25.39.12: Claudius [doubtless Quadrigarius] qui Annales Acilianos ex Graeco in Latinum sermonem vertit. On that of Claudius, see Peter I, 285-304. On the translation of Fabius' Annales, see Chassignet 1996: 58-62, with bibliography.

8. Dubuisson 1982, 1985; Mourges 1995; Adams 2003.

9. Which is diglossy. There were also cases of triglossy: for example Apuleius, who had learned Punic from his mother but wrote in Greek and Latin.

10. Which is bilingualism.

11. That is, self-translation: e.g. Apul. Apol. 6. 
idence that there is no natural link between language and identity as many believe in our modern times. ${ }^{12}$ Bilingualism and diglossy lasted throughout the principate and were reinforced by the acknowledgment of multilingualism after Caracalla's edict, which led some jurists to write treatises in Greek $^{13}$ and to recognize the use of other languages in law. ${ }^{14}$ Translations cannot be studied outside of this context. Only in late antiquity did things change, when the Roman Empire was divided and Latin became in the West the official language of Christianity, while Hellenism became linked to paganism ${ }^{15}$ and Greek considered as a foreign language (a lingua peregrina, as Augustine put it). ${ }^{16}$ Even in the sixth century, when Boethius, Symmachus, and then Cassiodorus tried to make Romans understand the importance of Greek philosophy, they had to set up a program of translations because their contemporaries did not know Greek. From now on, contacts with Greek culture came almost only through Latin translations, which created what Cicero had hoped for some centuries earlier: a real Latin literature for the Roman West. At the same time, Latin, which had been a cosmopolitan language, became more and more a vernacular one.

Romans were original in a second way: they explicitly acknowledged translation as a major component of their identity. I have tried to show elsewhere ${ }^{17}$ that this consciousness appeared at the end of the republic, after the conquest, and in a context of rationalization that involved many aspects of social and political life, especially the construction of cultural identity. Being eager to inscribe themselves in the history of other peoples, Romans created comparative chronologies, ${ }^{18}$ compared men and gods of different societies (Varro, for example, explained that Jupiter and Yaveh were the same ${ }^{19}$ ), or made lists of things, words, and institutions that they had borrowed from others. ${ }^{20}$ Translation was for them a way of thinking and of discovering the specificity of their own language. As Cicero writes:

12. This idea was common in the ancient world: as M. Finley has stressed, most historiography under Greek influence (Jewish or Egyptian, for example) was written in Greek. On the relation between identity and language see, for example, J. Elsner's remarks about Lucian in Elsner 2001: $149 \mathrm{ff}$.

13. For example Modestinus, who at the beginning of one of his treatises in Greek ( $d e$ excusationibus) declared that it was difficult to translate Roman law into Greek (Dig. 27.1.1).

14. See the references in MacMullen 1990: 32.

15. This explains why from the fourth century on translations were often the work of pagans reacting to Christianity.

16. Conf . 1.14.23. Augustine also reports that he hated Greek (graecas litteras oderam, 1.13.20) and that it was difficult for him to learn it (et ego quidem graecae linguae perparum assecutus sum et prope nihil: Contra litteras Petiliani 2.38.91).

17. Moatti 1997.

18. Moatti 1997: 77ff.

19. Lydus Mens. 4.53 (3.3 Wuensch). Sources and commentaries in Boyancé 1976: 153ff.

20. Sall. Cat. 51; Cic. Rep. 2.16.30, 3.3.4, Tusc. 1.1.1, 4.2.4; Symm. Ep. 3.11.3; Varr. Ap Serv. Aen. 7.176 (fr. 37 Fraccaro): dicit quid a quaque traxerit gente per imitationem. Here "imitation" is a kind of translation. On that theme, see La Penna 1976, Moatti 1997: 273ff. 
Postea mihi placuit ... ut summorum oratorum graecas orationes explicarem. Quibus lectis hoc assequebar ut cum ea quae legerem graece, latine redderem, non solum optimis verbis uterer ... sed etiam exprimerem quaedam verba imitando, quae nova nostris essent, dummodo essent idonea.

Cic. De Orat. 1.155

Afterwards I resolved ... to translate freely Greek speeches of the most eminent orators. The result of reading these was that, rendering into Latin what I had read in Greek, I not only found myself using the best words ... but also coining by analogy certain words such as would be new to our people, provided only they were appropriate.

Here is the paradox of translation: it helps, in effect, to reveal and enrich the original language. And probably, before being a way of transmitting Greek literature, translation was first of all for the Romans an exercise, albeit a difficult one, ${ }^{21}$ by which they would enrich Latin, by which they were trained in Latin. ${ }^{22}$ It was in a way a necessary mediation, which perhaps explains why, until the fourth century $\mathrm{CE}$, the number of complete translations seems to us so small. By translation, the bilingual Romans experienced the creativity of their own language. And the fact is that debates and theories about translation were exactly contemporaneous with the emergence of a linguistic consciousness and of the concept of latinitas..$^{23}$

The paradoxical function of translation can also explain why the Romans did not really care about being faithful to the Greek. In the praefatio to his Institutio arithmetica, which was a translation of that of Nicomachus, Boethius writes:

At non alterius obnoxius institutis artissima memet ipse translationis lege constringo, sed paululum liberius evagatus alieno itineri, non vestigiis insisto.

Boeth. Inst. arith., praef. 3

I am not tied by another way of thinking, and I do not force myself to a strict translation. Wandering with some freedom, I follow another's road, not his footprints.

For Romans, translation was sometimes literal, but more often it consisted of adaptation, imitation, periphrasis, summary. ${ }^{24}$ Sometimes the original was simply

21. Cic. Rep. 1.66-67; also Quint. Inst. 10.5.2 and n.3 above.

22. Quint. Inst. 1.12, Cic. De Or. 1.154, Boeth. In Cat. 201.2.

23. For discussion of latinitas, see Opelt 1969, Desbordes 1991, Bloomer 1997.

24. Romans used various words to denote an act of translation (Traina 1970). Vertere implies a metamorphosis, which means that the translator can supplement or suppress something in the original text (Plaut. Asin. 11; Poen. 984; Jer. Ep. 57; Boeth. Inst. arith., praef. 3). Imitari or aemulari is used for an unfaithful translation (Sen. Contr. 7.1.2; Macrob. Sat. 6.1.2). Interpretari means a word-by-word translation, which seemed the worst to Cicero and Jerome (Cic. Fin. 3.15, 3.35; Jer. Ep. 57), but the best to Christians, who tried to respect the sacred language (August. De Doctr. 
a fount from which to derive a new idea or new theory, as is often indicated by Cicero. ${ }^{25}$ Romans' use of their Greek models was conscious and voluntary; but in specifying the nature of that use they employed notions that can raise many problems for us. ${ }^{26}$ It is also worth noting that the same words are used to designate extra- and intra-lingual translations: for example, interpretatio defined a wordto-word literary translation but also the jurists' interpretation of the laws. ${ }^{27}$ The Romans in fact acted toward Greek authors as they did toward their ancestors, imitating, rewriting, and criticizing them. Translation could thus be the equivalent of variation or imitation or creation.

In a way, for the Romans culture was always translation and adaptation, even from Latin to Latin. It was an endless movement, or rather a dialectical relationship of fidelity and movement. ${ }^{28}$ This idea of dialectical movement, which can be applied to translation of books, ${ }^{29}$ concepts, ${ }^{30}$ or quotations,${ }^{31}$ can also be used for art: the copies of Greek art that invaded the Roman world from the end of the republic were nothing but a form of translation-and we know how important that phenomenon was in the life of the Roman elite, but also how creative the exercise was. ${ }^{32}$ The same could be said about the copies of Roman art that proliferated in the Roman empire, such as imperial portraits, which at the same time seem to be replicas of a given type but also variants or transformations of the original models. As J. Pollini points out, "portraits were usually copied with greater freedom in the Roman period than in modern times" 33 - freedom in the copying of a portrait type and freedom in representing the actual physiognomy of the person portrayed. Such freedom seems to have the same significance, whether texts or portraits are being "translated": it illustrates the Romans' relation to analogy and comparison in all fields of thought ${ }^{34}$ (translation being sometimes

Christ. 2.11). Finally, we find exprimere (Catull. 65), by which translation is compared to a copy of a work of art (see also Cic. Fin. 3.4.15; Ter. Ad. 11).

25. See Moatti 1997: 274ff.

26. To which we must add the fact that it is hard to determine exactly what was translated or not (as Macr. Sat. 5.3 shows, this was also a problem in antiquity). Romans did not always spell it out: see the periphrasis of Plato in Tusculan Disputations, or the silent adaptation by Celsus of Titus Aufidius' work on medicine. When they did, they did not always translate from an original (as was probably the case with Cicero's Topics: Barnes 1997); sometimes they only summed up a long text (Cic. Rep. 5.5.7, De Or. 3.149-70).

27. Sen. Contr. 7.1.27; Macr. Sat. 6.1.2.

28. To use the title of Bachir Diagne 2001.

29. For a list of these translations see Kaimio 1979.

30. See for example Powell 1995.

31. The quotations are numerous in various texts, jurisprudential as well as philosophical. But quotation was not always pointed out. Allusion was a cultural practice of the elite: see for example Sen. Ep. 44.4, which implicitly quotes Plato's Theaetetus.

32. Bieber 1997; Settis 1989. Our understanding of translation highlights the phenomenon of copies of art, and generally confirms the analysis of some historians of art, e.g. Gazda 1995 and 2002.

33. Pollini 1987: 9. Also Pollini 1999: 731ff., Zanker 1983.

34. Including the law-see Thomas 1997: 17-18. 
defined as metaphorâ). And it makes manifest the Romans' conception of identity as something under constant construction, in constant emulation with others, as well as their particular ideas of authority and of accuracy.

What is common to all these forms of translation (of texts and of art) is that they pertain to imperialism. Undoubtedly, translation sometimes had noble aims: it was the only way for those who did not read Greek to have access to the masterpieces of that culture; ${ }^{35}$ it was also necessary, as we have indicated, for intellectual education. But translatio studii was above all linked to translatio imperii. What was at stake was not only to increase Latin literature, but also to become culturally independent and to make Rome the intellectual center of the world. This idea was explicitly expressed in texts until the sixth century. We find it for example in Cicero:

Quam ob rem hortor omnes qui facere id possunt ut huius quoque generis laudem iam languenti Graeciae eripiant et transferant in hanc urbem.

Cic. Tusc. 2.2.5-6

I encourage all who have the capacity to wrest from the now failing grasp of Greece the renown won from this field of study and transfer it to this city.

Or in St. Jerome:

nec adsedit litteras dormitanti ... sed quasi captivos sensus in suam linguam victoris iure transposuit.

Jerom. Ep. ad Pammachium 57.6

The point is not to translate literally, but, I would say, to capture ideas and to translate them in Latin with the right of the conqueror.

Or in Boethius:

attuli non ignava opum pondera ... sed ea quae ex Graecarum opulentia litterarum in Romanae orationis thesaurum sumpta conveximus.

Boeth. Instit. arith., praef.

I did not offer you vain goods . . , but goods I have removed from the copiousness of Greek culture so as to bring them to the Roman treasury. ${ }^{36}$

Thus, translation was for the Romans a way to create their own cultural patrimony ${ }^{37}$ (the other means was the construction of their own antiquitas, but here also they used Greek forms-dialectic and all the instruments of logic ${ }^{38}$ ). In the words of Walter Benjamin, "history is that of conquerors and cultural legacy is nothing else but the booty exposed by conquerors ... cultural documents are

35. Cicero's idea (Fin. 1.1ff.), but especially that of the translators in late antiquity.

36. See also Cassiod. Inst. 2.3.1, Var. 1.45.

37. Moatti 2003.

38. Moatti 1997, chapters 3 and 4. 
always documents of barbarity." 39 This conception is easy to apply to Rome, and perhaps its paradigm is Rome. The Roman use of translation to construct their cultural patrimony also allowed them to consider themselves as heirs. They even believed that their role was to archive Greek successes and achieve what the Greeks failed to do. ${ }^{40}$ Rome became in a sense the memory of Greece, and Greek history one element of the Roman past. To become Roman, we could say, it was first necessary to understand, to speak, and think Greek. ${ }^{41}$ Perhaps this state of affairs, that is the acknowledged status of heirs, can help us to define Romanity, if this term has a sense, and even European modernity. ${ }^{42}$ It is undoubtedly the most original feature of Roman civilization. ${ }^{43}$

Translation also imposed the idea that culture was universal, that it did not belong exclusively to Greeks, that production of norms and of works had not only a local value, but a universal one. It was the intention of Cicero to establish this point in philosophy; something similar happened in art and architecture. ${ }^{44}$ Homer, the tragedians, Xenophon, Aristotle, Plato did not any longer belong to the Greeks, they became part of a universal patrimony. This message was reinforced by the increase of human mobility. It is banal to record the cultural travels made by Romans and the number of Greek intellectuals who came to Rome: ${ }^{45}$ in this sense, migration as well as translation had a major part in the process of acculturation, in the creation of a common world, with the same values, the same culture, inherited but selected and redefined by Rome.

It is interesting to note that the same thing happened with Christianization. Evangelization was achieved by translation into Greek and then into Latin, and also by traveling. Saint Paul's case is paradigmatic, since he covered a distance of about ten thousand miles. In the seventeenth century the Jesuits identified the same techniques to help Christian expansion in the world: translation and missions, that is to say movement.

In fact, Roman universality shares many aspects with Christian universality. Both had the ambition to transform human diversity into unity, or rather to rediscover the original human unity. Romans tried to do this by law, by the extension of citizenship, which was first of all a juridical status that could be

39. Benjamin 1991: 356 .

40. This partly explains the Romans' use of different styles of Greek art or literature in the same work or at the same period: Hölscher 1987, Settis 1989 n.24. On the idea of perfection, Cic. Tusc. 1.1.2, 4.1.1, Rep. 2.16.30.

41. See the interesting remarks of Wallace-Hadrill 1998, who, however, says nothing about translation.

42. On this question, Moatti 1997: 258ff., and Brague 1992.

43. Moatti 1997: 255ff.

44. Cic. Tusc. 2.2.5-6; Nat. D. 1.4.8ff., Div. 2.2; Hor. Sat. 2.10.20-35, Carm. 4.3.17-24, etc. Propertius also wanted to transfer elegy from Greece to Rome: he wanted to be "the Callimachus of Rome" (3.1.1-4, 4.1.63). See also Plut. Cic. 5; Moatti 1997: 84-86; Habinek 1998: 65-66.

45. Polyb. 31.24.7, Cic. Brut. passim. La Piana 1927, Bowersock 1965, Balsdon 1979: 54, which gives a list of all the Greeks living with rich Romans; Rawson 1985: 5ff., Crawford 1978, Noy 2000 . 
extended ad infinitum; so for them Roman citizenship could transform Gauls, Africans, Syrians into real human beings. ${ }^{46}$ Christians tried to do the same by religion, which made it possible, as Saint Paul said, to transform foreigners and citizens into simple and equal human beings. ${ }^{47}$ In addition, both were in the position of heirs, in keeping with a mother culture, which considered itself as founder of civilization and was also exclusive (Greek culture for Romans, Jewish culture for Christians). Finally, for both, translation had universalized the message, showing that identity could be dissociated from language and from locality. ${ }^{48}$ In that way, Christianism is unintelligible without Roman universalism. It can even be regarded as an extension of Roman universalism.

\section{HUMAN MOBILITY}

Translation is associated with migration in yet another way. In both cases what is brought into question is the definition of identity. If language is not enough to identify a person, what is? More generally, what was the nature of personal identity in Roman antiquity? The question is not anachronistic. In ancient societies, people had to prove their identities on various occasions, and we read of many falsifications or errors about identity in Greece as in Rome. But the question is quite different depending on whether we understand it from a static or a dynamic point of view. In face-to-face situations, oral testimony (of friends, of parents) could help someone to prove his own identity; it could be sufficient to attest that he had done something or had such and such a privilege. It did not at all exclude the use of documents, but documents did not have a convincing value in themselves; they were principally the record of oral testimony. ${ }^{49}$ They supplied memory not proof. It was quite different in the case of migration: how was a foreigner, a man or a woman coming from another place, able to prove his or her identity? How could the authorities identify them? By identity, I mean not only civic status but religious and social status as well.

Migration is a considerable phenomenon and, as Fernand Braudel has written, Mediterranean history is not fully understandable without it. As for the Romans, it can easily be shown that migration increased greatly from the end of the republic and the beginning of the principate, chiefly because of peace. Ancient literature and epigraphy confirm the point: ${ }^{50}$ for example, the funerary inscription of an artisan who made seventy-two journeys from Phrygia to Rome (IGR 4.874). We could also refer to the people Paul encountered during his travels: some of them were officials, some were forced to travel, as prisoners or delinquents, some

46. On the link between civitas romana and humanitas see Moatti 1997: 239ff.

47. Gal. 3.28; Rom. 2.9-10, 10.12 .

48. On the Christians' interest in translations, see Sachot 1999.

49. See the remarks of Gardner 1986; for Athens, Scafuro 1994; on falsifications Reinhold 1971.

50. The bibliography is very important: for example, d'Escurac 1988, Ricci 1994, Haley 1991, with extensive bibliography. 
were free travelers (artists, merchants, students). This human mobility in Roman society has often been studied, chiefly from three points of view: the development of travel and commerce, made safer by the principate ${ }^{51}$ the cosmopolitan character of the cities,${ }^{52}$ finally, the causes of migration, such as penury of material or human resources. ${ }^{53}$

There is however another aspect which has never really been studied and which is the purpose of a comparatist program I have set up: the control of that human mobility. A study that raises questions concerning the maintenance of public order, the capacity and zeal of states to control their own territory (at the frontiers or inside) as well as the means of identifying people who moved, and thus the progress of writing. and of liberty. ${ }^{54}$

In our times of globalization and of construction of Europe as a free space, it is easy to understand that territories are pure constructions, that identity can be plural, that freedom of movement is not a fact of nature. In the second and third century, Greek sophists, such as Aristides in his eulogy of Rome (section 61) or pseudo-Aristides in the emperor's eulogy (section 37) emphasized and praised the freedom of movement found in the Roman empire:

Cannot everyone go with complete freedom where he wishes? Are not all harbors everywhere in use? Are not the mountains as secure for travelers as the cities for inhabitants? Has not fear gone everywhere? What straits are closed? Now, all mankind seems to have found true felicity! Ps. Arist. Regarding the Emperor 37, trans. C. A. Behr

Did this vision correspond to reality, or was it an official commonplace, a way to celebrate the universal vocation of Rome? It is worth seeing if the reality corroborated this representation and questioning the links between the idea of liberty of movement and its imperial context, the logic that governed the regulations about mobility and above all the definition of "liberty of moving." In the seventeenth and eighteenth centuries, it was recognized as a natural right (a subjective right), but what about in ancient societies? Was it anything other than safety? The notion of negotiation will be perhaps helpful to give a first answer. The imperial territory was the result of conquests but also of treaties by which the inhabitants had become peregrini, a word that had a specific connotation: it referred not only to the juridical status of provincials, but also to the idea that provincials were protected foreigners. As Cicero wrote in De Officiis, in archaic times there was only one word to define the foreigner: hostis, which was the equivalent to hospes, guest; then the latter sense was given to

51. Young 2001 .

52. Noy 2000.

53. Horden and Purcell 2000.

54. See now the first publication of this program: Moatti 2004. I present here only some axes of that research. 
peregrinus, while hostis came to mean enemy. Peregrini were in fact foreigners with whom Rome had established a negotiated relationship and who thus could travel safely in the empire. We could suggest that the Roman territory was free because it was a juridical space. Liberty of moving could be then defined not as a natural right, but as a positive fact, shaped by numerous institutions and based on negotiation. But this liberty did not mean absence of regulation.

\section{IDENTITY AND IDENTIFICATION}

We must set aside any anachronism. The goal is not to imagine a systematic control of persons in the Roman empire, nor to look for passports or identity cards in antiquity, but to define the Roman forms of control and their evolution. This control could sometimes be limited to certain places, certain populations, or certain days. It could be nonexistent too, or could be provided by the mediation of corporations or of special institutions that neutralized the segmentation of the society produced by mobility. In Greece proxenia, in Rome hospitality, in medieval times privileges played that function. In the last instance, foreigners were protected, but also controlled, for they had to prove their right to privileges, and then their identity and their origin.

All societies needed to make distinctions among their members and between their members and foreigners. But the means and degree of accuracy changed according to times and places.

In societies where identity cards did not exist, identification was often based on social networks and witnesses (or delation): thus they are often defined as "sociétés de l'interconnaissance." But what were the means for a migrant? The sources allude to many different ones: oath, signature, use of signs like insignia (a ring, clothes, shoes) or objects (seals, symbola, tesserae of hospitality ${ }^{55}$ ); written documents, public or private (a letter of commendatio ${ }^{56}$ a document of immunity could play this role), physical description ${ }^{57}$ or professio (declaration of name, ${ }^{58}$ filiation, and narration of biographical elements given as true). All these means reveal the low needs of identification and the fluctuating character of identities in the context of human mobility. A narration, for example, could hide the true civic identity which, in fact, did not interest the authorities. In the Acts of Justin the Martyr, the prefect Rusticus asks Hierax, one of Justin's followers who have come to Rome: "And your parents, who are they?" And Hierax answered: "Our father is

55. On hospitality Benveniste 1933, Gras 1985: 206ff. On symbola Gauthier 1972.

56. From Cicero's letters in the republic to late antiquity: Symmach. Ep. 76, 67.

57. In Greco-Roman Egypt, for example, for private transactions or on public documents, a physical description was briefly written near the name (scars and other particular features), perhaps because people often had more than one name. On the Egyptian evidence, see the classic study of Hasebroek 1921.

58. But, as Carlo Ginzburg points out, the more complex a society was, the less the name sufficed to identify someone: Ginzburg 2000. 
Jesus Christ and our mother is the faith in him." ${ }^{59}$ It was also Jesus' question to his followers: "Who am I according to the crowd? . . But for you, who am I?"60

Appearance also (clothes, objects, particular signs, behavior, voice ...) was another important way of identifying migrants. ${ }^{61}$ Pap. Giessen 40, which contains the famous edict of Caracalla, ${ }^{62}$ also contains a decree issued in March $216^{63}$ by which all the country folk who had fled from other parts of Egypt were expelled from Alexandria. Caracalla says that they are easy to detect: "genuine Egyptians can easily be recognized among the linen-weavers by their speech, which proves that they have assumed the appearance and dress of another class; moreover their lifestyle far from civilized manners reveals them to be Egyptian country folk." We can see here how arbitrary and hasty identification was and how it was easy to falsify identity. But the importance of looks, so much attested by the numerous stories of disguise and travesty ${ }^{64}$ and by the papyri ${ }^{65}$ is not only related to identification by others; appearance could -also be a way of asserting one's own identity. Thus Apollonius of Tyana, coming to Rome in 93, under Domitian's prosecution of the philosophers, wore the long linen mantle and showed his long hair to assert his identity as a philosopher and defy the emperor, while he ordered his follower, Damis, to change his appearance in order not to risk going to jail (8.15). The story lends itself to several interpretations: we might say that mobility such as that of the sage and his entourage was associated with a capacity for changing identity according to place; or we could believe that travel was a metaphor for the long road of the sage to an understanding of his true identity and that hindrances were means for him to be more conscious of what he was; or we could even understand that the process of identification has nothing to do with true identity. This shift in identities may in fact be compared to the modification we have already noted in the transmission of imperial portraits, which were often altered and adapted in the provinces. ${ }^{66}$ We might say that the Romans played with identities as artists did, and that our difficulty in determining the original portrait of an emperor is a kind of metaphor for the main issues concerning identification in the ancient world.

59. Dubois 1994: 4, 8, 18-20 (translated here by Moatti).

60. Luke 9.18-20.

61. On the links between appearance and identity, Vernant 1988; Frontisi 1991; for Rome Bettini 2000: $313 \mathrm{ff}$.

62. Girard 1977: 203 = Hunt and Edgar 1932-1934: II, 215.

63. On the date see Lukaszewicz 1990.

64. For example, Suetonius (Rhet. 1.3) tells the story of merchants who try to deceive customs officials by giving a slave they did not want to declare the bulla and the praetexta. See also Plut. Crass. 4,3, Ant. 8, 14, 18, 22, 35, 41; Cass. Dio 40.8-9, 9.2.

65. In a papyrus from Oxyrhynchos (second century $\mathrm{CE}$ ), a fugitive slave is described thus: "totally ignorant of Greek, tall, thin, no beard" (P. Oxy. 51.3617); another papyrus aludes to his way of talking: "chatters in a discordant voice," or his way of walking: "walks as if he were a very important person” (P. Oxy. 51.3617).

66. Pollini 1987: 11-12 n.28. 
All these means, witnesses, looks, declarations disclose what we might call, following Paul Ricoeur, the "aporia of identification." ${ }^{67}$ For neither one nor the other was a trustworthy means. But they reveal Roman society's mode of believing and the degree of falsification or error it tolerated. ${ }^{68}$ The tolerance depends in fact on the objectives of the identification. Ancient societies did not need to identify all their inhabitants: identification could be left to social networks, to indifference, or to uncertainty. In the same way, all people did not need to be identified. Apollonius and the Christians could have escaped identification: when they arrived at Rome, they could have lived quietly without any questions if they had wanted to. But their desire to affirm their strong personal identities provoked administrative identification.

This space of liberty and negotiation in the process of identification, which can also be seen in the flexible uses of declarations of birth, ${ }^{69}$ needs to be studied. It is of considerable importance since it helps us understand what was at stake in control and identification, what constituted a person from an administrative point of view, and finally in what proportion mobility influenced the transformation of the means of identification. It has frequently been asserted that the control of mobility has increased, in modern times, the administrative capacity of states: what is the case in ancient societies? This story (which remains to be written) is a major part of my project.

\section{THE NATURE OF THE SOCIAL LINK}

Inquiry into control and identification has other implications. It opens up a political debate on the nature of social bonds and the political community. As Michael Walzer observes, one of the main axes of political reflection has been to determine with whom citizens agree to share the city and its goods. ${ }^{70}$ It seems that even cosmopolitan societies create local boundaries. Is there always a part that must be closed? And is it the same at the entrance and the exit? Plato, who considered the mixture of people a cause of moral degradation, proposed

67. Ricoeur 1985: 355-58 discusses "l'aporie de l'identité."

68. Roman law distinguished between falsification of a juridical status and error with respect to person or status. The difference lies in the existence of bona fides, as shown by the action of the emperor Claudius, who repressed the usurpations of status (Suet. Claud. 25.3) but gave civitas to peregrini who, having the tria nomina by error, thought they were citizens (Tabula Clesiana $=C I L$ $5.5050=$ FIRA I, 71). As for errors of person, imperial law distinguished error of identity, which implied the invalidity of an act, and the error of quality of persons, which had no influence on the act (Dig. 18.2.1.3, 14.3.6.1, 1.14.3). Cf. Castello 1951: 197ff.

69. Created under Augustus they were never generalized and never sufficient to prove one's identity. As the emperor Gordian III put it, "omission of a birth declaration does not make illegitimate the legitimate children, as much as a declaration cannot introduce a foreigner to a family" (P. Teb. 2.285 = FIRA I,90 = Girard 1977: 8.23). There were numerous cases where people had to prove their age, but the epigraphical documents show that an oath was sufficient most of the time (cf. lex Irnitana [AE 1984] 31, ch. G).

70. Walzer 1983: $70 f f$. 
in his Laws some devices to regulate the entrance of foreigners and to limit the movement of citizens:

First, no man under forty years old shall be permitted to go abroad to any place whatsoever; next, no man shall be permitted to go abroad in a private capacity, but in a public capacity permission shall be granted to heralds, embassies, and certain commissions of inspection.

Laws $12.950 \mathrm{~d}^{71}$

Under what conditions does a community concern itself with emigration of its citizens and with what happens to them afterwards? Even the most open societies have discussed these issues, and from Homer's Odyssey to Swift's Gulliver's Travels, literature has shown all kinds of solutions to the question. There is in fact a great range of social choices and practices from hospitality to hostility: assimilation, integration, ghettoization, exclusion, or discriminatory measures. And these choices are revealed also by the juridical categories that serve to name the different kinds of migrants and by the terms through which citizens are distinguished from other inhabitants. For language, like territory, entails authority and submission.

\section{THREE LEVELS OF INQUIRY}

The study of human mobility invites different levels of inquiry. I present here only three examples.

First, the entry into towns of transient persons: artists, country men, merchants, students. We know, for example, from an imperial constitution of Valentinianus I dating to the end of the fourth century, which documents were necessary for students in Rome. ${ }^{72}$ At their arrival they had to supply to the magistri censuales, who worked with the praefectus urbi, their provincial governor's written authorization to leave the province, a dossier that was composed of the name of their town, a birth certificate, some information about their scholastic activities; then, the magistrate needed to report to the emperor on the progress of their studies, as well as the students' activity in Rome; their stay was limited to two years, and so on. All this shows a society used to controls and police surveillance, as is indicated also by the action taken against the vagrants, the beggars, and all the itinerants at this time and later. ${ }^{73}$ It is more difficult to determine when these instructions were first established. We find other references to students one and half centuries earlier, for example in a passage from Ulpian that shows that their status in civil law was very particular:

ponamus enim studiorum causa Romae agere: Romae utique domicilium non habet et tamen dicendum est, si vi domus eius introita fuerit,

71. Loeb translation.

72. CTh 14.9.1

73. Mazzarino 1951: 244, now Neri 1998. See also Ambros. De Off. 3.44.52. 
Corneliam locum habere: tantum igitur ad meritoria vel stabula non pertinebit: ceterum ad hos pertinebit, qui inhabitant non momenti causa, licet ibi domicilium non habeant.

$$
\text { D. 47.10.5.5 [Ulp. } 56 \text { ad Edictum] }
$$

Let us take someone at Rome as an example for the purpose of study. A man may not have his residence at Rome, but if his house at Rome is entered by force, it must be said that the Lex Cornelia is applicable. But it doesn't apply to temporary lodgings or brothels (or taverns?). But it does concern those who are not merely transient inhabitants, although the house is not their normal residence.

We can see here the very precise distinctions between residents (those who have domicilium in a city which was not their place of origin), temporary residents (the students), and transient inhabitants (qui inhabitant momenti causa), which reveal a great attention to the judicial problems of human mobility. In fact, mobility transformed the relation between man and space. It explains in part the emergence in law, at the end of the republic, of these new categories (origo, domicilium, incolatus, qui commorantur) ${ }^{74}$ which did not aim to fix people to a place, as has often been said, but to localize better the people who in that period moved very much, to control them better, and to define more precisely their identity.

The second aspect of inquiry about human mobility concerns the crossing of frontiers. Can we say, with Dick Whittaker, that the frontiers were all free $?^{75}$ I don't think so. Tacitus and Cassius Dio attest, for example, that the German merchants were sometimes controlled at the frontier, ${ }^{76}$ a point confirmed by ostraka discovered on the limes Tripolitanus in $\mathrm{Bu} \mathrm{Njem}$, which bear inscriptions about the entry of barbarians into the territory of the empire. ${ }^{77}$ However, these attestations are of a different nature. Careful examination of these documents shows that the control did not really concern the frontier itself, but some particular tribes. If the Hermundurians could enter Roman territory freely, sine custode as Tacitus puts it, ${ }^{78}$ we are told by Cassius Dio that this was prohibited to the Quades; that Commodus decided to limit to once a month the encounter between Roman and German merchants, in one place, and under control. ${ }^{79}$ On the oriental frontier, the same could be said: the treaty between Rome and Persia in 298 CE specified that commerce between the two nations was authorized in Roman territory only at Nisiby and in Persian territory only in two towns. ${ }^{80}$ It is very interesting to see

74. Thomas 1998 (with bibliography); Baccari 1996.

75. Whittaker 1989: 104.

76. Tac. Hist. 4.64-65; Cass. Dio 71.15, 72.11.3, 73.2.4.

77. Marichal 1992: 110 n.71, n.101.

78. Tac. Hist. 4.64-65.

79. See n.76 above.

80. On this treaty see Andreotti 1969 and CJ 4.63 .4 (408 or 409): Impp. Honorius et Theodosius A.a. Theodoro pp. Mercatores tam imperio nostro quam Persarum regi subiectos ultra ea loca, in 
that diplomacy took into account the problem of human mobility and commercial relations. And such interest was not rare, as can be seen in the old treaties between Rome and Carthage that are described by Polybius. ${ }^{81}$ What is also interesting in the treaty with Persia is that its provisions were then extended to other provinces. At the end of the fourth century, comites commerciorum can be found:

Si qui inditas nominatim vetustis legibus civitates transgredientes ipsi vel peregrinos negotiatores sine comite commerciorum suscipientes fuerint deprehensi, nec proscriptionem bonorum nec poenam perennis exilii ulterius evadent.

CJ 4.63.6 pr. Imperatores Honorius, Theodosius AA Maximo comiti sacrarum largitionum

Those who have been caught while traveling through cities quoted in ancient laws, or giving hospitality to foreign merchants without a comes commerciorum, won't escape from a proscriptio bonorum nor from a definite exile.

As we learn, the duty of the comites was to control foreign merchants and to register their names, to deliver to them authorization to come to cities where commerce was allowed. And it was prohibited for Romans to give such merchants lodging without authorization. ${ }^{82}$ So the passage was not absolutely free, and the frontiers not completely delimited (see the liberal attitude of the Romans to the nomadic tribes), but the control depended on people, on period, and also on political situations. This Roman conception has to do with the conception of the foreigner, which was not territorial, and with the existence of pluri-territoriality inside the empire. It is the reason why controls were neither permanent nor systematic, and were not only the fact of central authorities. It is only in the fourth century that the conception of sovereignty became more territorial.

The third axis of my research concerns movement inside the empire. Here the problem is quite different: the sources do not agree among themselves. This variation may come from chronological discontinuities or, rather, from the fact that Roman policy was not the same everywhere. So it is not easy to give general conclusions, as is shown for example by the case of provincial frontiers. We have much information about Egyptian ones. I have shown in another article,

quibus foederis tempore cum memorata natione nobis convenit, nundinas exercere minime oportet, ne alieni regni quod non convenit, scrutentur arcana. Nullius igitur posthac imperio nostro subiectus ultra Nisibin Callinicum et Artaxata emendi sive vendendi species causa proficisci audeat nec praeter memoratas civitates cum Persa merces existimes commutandas: sciente utroque qui contrahit et species, quae praeter haec loca fuerint venumdatae vel comparatae, sacro aerario nostro vindicandas et praeter earum ac pretii amissionem, quod fuerit numeratum vel commutatum, exilii se poenae sempiternae subdendum.

81. Polyb. 3.22-26; cf. Scardigli 1991 and Bresson 2004.

82. CJ 4.63.6. See also the imperial constitutions on the control of maritime frontiers given to curiosi litorum and to custodes: CTh 6.29.10 from Theodosius in 412, and 13.5.5 (329) and 17 (396) from Valentinian II; Gaudemet 1958: 215; Goffart 1980. 
based on papyri, literary texts, and the famous Antonine document, the Gnomon of Idiologus, that the very strict control for entry to or exit from Egypt was in the Roman period based on two types of documents: a nominal pass (diploma) for persons or a fiscal document for goods. ${ }^{83}$ The person who wanted to leave the province from the port had to send a request to the prefect, an application which would be signed by the prefect and sent to the procurator of the exit port: this last acted as an emigration inspector as well as a tax collector. What is interesting is the importance and regularity of the control as well as the fact that both immigration and emigration were controlled. It does not seem to have been the same in all the entrances of the province, nor in other provinces. We can find in the Digest that a provincial governor had authority only over the inhabitants of the province: so what about the merchants and the travelers? We can see also from Pliny that some towns situated at the entrance of other provinces had a garrison, but it was not the case in his own province. ${ }^{84}$ We can't really say what constituted imperial policy in this matter. Then again, neither could Pliny, who did not understand Trajan's refusal to give him a garrison! Had they only a symbolic function at some entrances to the most important provinces?

We could say therefore that the Roman empire lacked not control, but unity and regularity. Such was not the case, however, with the mobility of officials. Here the unity of imperial policy was achieved quite early. As under the republic, Roman officials used passes (diplomata) which allowed them to make requisitions of the provincials. ${ }^{85}$ Beyond the fact that these requisitions had often been regulated, what is worth noticing is that the diplomata themselves were controlled. Initially issued by emperors, governors, and the senate, they were, from the end of the first century, issued solely by emperors ${ }^{86}$ as can be established from Domitian's letter to his Syrian procurator, Claudius Athenodorus, in which the emperor allows requisitions only if diplomata have been issued by himself. ${ }^{87}$ This reform, largely confirmed by other sources, Pliny for example, ${ }^{88}$ was very important: it aimed to unify the issuing of official documents and also, undoubtedly, to reduce the governor's influence. ${ }^{89}$ This development shows that a diploma was not so much a document of identity as a kind of commendatio, sealed by the emperor.

Domitian's reform is one of many examples that prove the emperors' interest in controlling public documents. This control had in fact begun at the beginning of the principate. We might refer to the Augustan repression of falsification of archives-regulations against the access to archives without the scribe's

83. Moatti 2000.

84. Cf. Plin. Ep. 10.77-78 (and Black 1995: 11ff.).

85. On the cursus publicus see di Paola 1999.

86. Cf. Mitchell 1976: 126.

87. IGLSyrie V, 1998 = MacCrum 1966: no. $466=$ Girard 1977: 435ff.

88. Pliny Ep. 10.46, 10.121.

89. Line 20: "for it is unfair that somebody of a certain rank and a certain social influence should allow requisitions that nobody but myself can authorize." 
authorization, ${ }^{90}$ against the destruction or falsification of an official document, ${ }^{91}$ or against the imitation of a signature. ${ }^{92}$ We could also invoke the Claudian attempt to protect official documents with technical changes (I allude to tabulae ceratae used for birth certificates, locationes, societates, etc.). ${ }^{93}$ These reforms reveal the greater value given to written documents by the emperors, from a symbolic as well as from a practical point of view. And that major interest in writing had great consequences on political society: it undoubtedly increased the imperial control of society, as Cassius Dio observed. ${ }^{94}$ This development can be documented through study of written communication between imperial center and periphery, another form of movement.

\section{COMMUNICATION}

Communication is closely linked to translation and migration. Translation, as we have said, was a way of governing a bilingual empire, as was human mobilityby legations, emperors' or officials' travels, ${ }^{95}$ and written communication.

Emperors used the traditional forms of written communication, namely correspondence and edicts, which, as in republican times, were to be read by a town crier (praeco) to the people gathered in a public place, whether in Rome or in the provinces. An edict could be either an $\operatorname{order}^{96}$ or an announcement ${ }^{97}$ or a dialogue with the people - a reaction to demonstrations, graffiti, rumors, a response

90. Dig. 48.13 .11 (9).5 (Paul., lib. sg. de iudic. public.): Senatus iussit, lege peculatus teneri eos qui iniussu eius qui ei rei praeerit, tabularum publicarum inspiciendarum describendarumque potestatem fecerit. "The Senate has ordered that those persons should be liable under the law on embezzlement of public money who, without the orders of the person in charge, give permission for the inspection and transcription of public records." We can note here the distinction between the consultation (inspicere) and the demand of a copy (describere), that implying the existence of a double right, which is very important to the study of access to archives.

91. Dig. 48.13.10 (Venuleius Saturninus, lib. tert. iudiciorum publicorum): Qui tabulam aeream legis formamve agrorum aut qui aliud continentem refixerit vel quid inde immutaverit, lege Iulia peculatus tenetur. Eadem lege tenetur qui quid in tabulis publicis deleverit vel induxerit. "Anyone who takes down the bronze tablet of a law, or of an official map of the distribution of land or a tablet containing anything else, or alters any part of it, is liable under the lex Iulia on embezzlement. Anyone who makes deletion from or addition to the public records is liable under the same statute."

92. Dig. 48.10 .23 (Paul. lib. sing. de poen. pag.): Quid sit falsum, quaeritur: et videtur id esse, si quis alienum chirographum imitetur aut libellum vel rationes intercidat vel describat.... What is forgery? It appears to be [forgery] if someone imitates another's handwriting, or tampers with, or copies a written document or account...."

93. Cf. Bove 1984; Camodeca 1993. More recently, Meyer 2004, especially $121 \mathrm{ff}$.

94. Cass. Dio 53.19.1-6.

95. On all forms of relations between center and periphery, see Millar 1977.

96. For example Claudius' edict on vehiculatio (ILS 214) or Caesar and Augustus' edicts on the violation of sepulcher (FIRA 1.69). See Millar 1977: 255-56.

97. To announce, for example, comitia or enrolments. Cf. Mommsen 1984: 236. The edict that was to be read out and in which emperors used the first person (Vespasian's edict to the Vanacini [CIL X, $8038=$ FIRA I, 72], must be distinguished from the edict that was to be only displayed and eventually copied, in which emperors used the third person (e.g., Claudius' edict on the city of the Anauni: CIL 5.5059= FIRA 1.71). 
to a question, or a question, or an explanation. ${ }^{98}$ In Rome, the prince was less visible than the republican magistrates: so writing tended to replace the physical relation of the contiones, ${ }^{99}$ in the provinces, edicts constituted, together with the ceremonial, an important part of the Roman presence. ${ }^{100}$

Beyond these traditional forms, however, emperors created new ones that were only written. ${ }^{101}$ There were for example the documents issued by the civil and military administration-proofs of nomination to an office or of a benefit; ${ }^{102}$ there were mandata, instructions given to governors when they left Rome for their province, and iussa, circumstantial orders sent by letter to governors or officials; ${ }^{103}$ there were rescripts (rescripta) - answers to petitions and requests coming from cities, governors, procurators, or individuals. ${ }^{104}$ All these documents were also registered under the control of officials in the imperial archives, the commentarii, ${ }^{105}$ which were organized thematically and chronologically, ${ }^{106}$ and whose continual use from one emperor to another expressed the continuity of the state.

Thus, if a part of imperial communication was to be read out, as in earlier times, a great part now passed through writing. This situation also obtained in

98. Suet. Aug. 53.1: Augustus reprimanded the people by an edict because they called him "Master"; Tac. Ann. 1.78.2: the people asked Tiberius to suppress taxes on sales; Tiberius explains, through an edict, why he could not do it; Tac. Ann. 5.5: Tiberius reprimanded the plebs; Suet. Galb. 15: the people called for Tigellinus' life; Galba refused and displayed an edict in which he reprimanded the people for their cruelty. Other examples: Suet. Aug. 42.1-2; Tac. Hist. 1.76; Pliny Pan. 65; Cass. Dio 69.16.3. See also Benner 1975: 158-61. A story told by Cassius Dio shows that the edict could be true: by an edict, Vespasian expelled the astrologers from Italy with a precise delay; they replied by posting a letter asking him to die before a certain date (65.1.4)!

99. We have few examples of contiones organized by emperors: cf. Millar 1977: 369.

100. Millar 1984: 41.

101. A good description of these means in Coriat 1997: 71ff.; Marotta 1999.

102. On the documents (codicilli) confirming an appointment to a post, see now Marotta 1999; on military diplomas, Roxan 1981; Weiss 1997.

103. On the mandata see Marotta 1991, esp. 86ff. Pliny's correspondence shows the importance of circumstantial orders: Eck (1999: 344) calculated that in two years Pliny sent sixty-one letters to Trajan and Trajan answered forty-eight times.

104. A good analysis in Coriat 1997: 71ff. This system can also be found at the provincial level. K. Hopkins records, as a well-known fact, the 1804 petitions received by a governor in two and a half days (Hopkins 1991: 137).

105. For example, after a concession of citizenship, Trajan ordered his decision to be registered in his commentarii (Pliny Ep. 10.105): "I have accordingly granted the citizenship to such of his freedmen for whom you requested it, and have directed the patent to be registered (in meos commentarios): I am ready to confer the same on the rest, whenever you shall want me to."

106. We know the liber libellorum rescriptorum et propositorum (as shows the petition to Commodus from the coloni of the Saltus Burunitanus, in CIL VIII 10570 and $14464=$ FIRA I, 103) or the commentarii civitate donatorum (Tabula Banasitana, in Girard 1977: 478 ff.). The rescripts were registered with great precision in the imperial commentarii, even in Greek if it was the language of the rescript (Dig. 14.2.9 [Maecenatus ex lege rodia]; 50.6.6.6 [Callistratus 1 de cogn.]): Ulpian (Collatio 1.11.1) has conserved Hadrian's decision (rescripsit) with the verba of the consultation. As explained by E.Volterra, "this passage shows that a third-century jurist could have access to the previous emperor's rescripts and that the archives conserved not only the rescript itself but also the words of the consultation which was an important part of the imperial decision" (Volterra 1971: 856). 
the relationships between emperors and senators. Not only could the emperor be informed by the acta senatus of what had been said in the Curia, ${ }^{107}$ but from the time of Augustus, imperial orationes were written ${ }^{108}$ and, above all, from his time, the emperor began to send senators his opinions ${ }^{109}$ or his questions in writing and to receive memos and reports from them. ${ }^{110}$ So he consulted them more and more as if they were only experts: in a way, writing revealed the separation between decision and deliberation. ${ }^{111}$ We can easily imagine that when, after Augustus' death, senators received the breviaria imperii, a kind of post mortem memoir, they were not surprised: ${ }^{112}$ it was as if Augustus kept on communicating with them after his death. Tacitus suggests that under Trajan these written relations no longer existed when the emperor was present at Rome. ${ }^{113}$ After him, however, it seems that they were still in use. ${ }^{114}$ In time the emperors were so often absent from Rome ${ }^{115}$ that they had to "govern by correspondence," to use Fergus Millar's expression. ${ }^{116}$

\section{THE DIFFUSION OF PUBLIC DOCUMENTS}

An increase in written documentation is well attested by the sources, which emphasize audiences given "to countless thousands of men, countless petitions (libelli) disposed of, so great is the pile of business accumulated from every part

107. Suet. Tib. 73.1 .

108. Suet. Aug. 85.4: Augustus also wrote his personal conversations; and from the time of Claudius, the quaestors were in charge of reading them: cf. Cass. Dio 60.2.2; Suet. Ner. 15; Dig. 1.13.2-3; Vespasian changed this custom and asked his sons to read out his speeches (Cass. Dio 66.10.5-6; cf. Talbert 1984: 179).

109. Cf. Cass. Dio 56.26: reading Augustus' letter addressed to the Senate about Germanicus; cf. Cass. Dio 53.23.6, 53.21.3 (and Talbert 1984: 434); Suet. Aug. 65.

110. Cf. Cass. Dio 56.26: about questions on taxes, "some opinions were communicated to Augustus by tablets (dia biblion)." A frequent procedure under Tiberius' reign: cf. Cass. Dio 55 (or 56).47 about the decrees passed in memory of Augustus: "For when some men proposed one thing, and some another, the senate decreed that Tiberius should receive suggestions in writing (dia biblia) from its members and then select whichever he chose." In the same way, during his military campaign in Germany, "Tiberius gave written orders," wrote Suetonius (Tib. 18). Cf. Tac. Ann. 4.39.1: "Sejanus meanwhile, dazed by his extravagant prosperity and urged on too by a woman's passion, Livia now insisting on his promise of marriage, addressed a memorial to the emperor (componit ad Caesarem codicillos). For it was then the custom to apply to him by writing, even though he was at Rome" (moris quippe tum erat, quamquam praesentem scripto adire). On the libelli sent by Sejanus to Tiberius, see Tac. Ann. 4.39, 3.68; Cass. Dio 53.23.6. The same thing about Nero in Ann. 13. 26-27: the consuls wrote to Nero to inform him of the senate's decisions; Nero refered to his consilium and answered in writing to the senate (Ann. 14.59).

111. Talbert 1984.

112. Suet. Aug. 101. On these documents see Nicolet 1988: $192 \mathrm{ff}$.

113. Ann. 4.39., as quoted above in n.110 and the commentary of Sherwin-White 1966: 578.

114. Marcus Aurelius refused to be too severe with Avidius Cassius' family, and in writing asked the senate to show clemency (SHA Avid. Cass. 11.4); cf. also Fronto ad Ver. 2.16: quid ad senatum quom debet loqui, epistulam scriberet.

115. Before arriving as emperor in Rome in 70, Vespasian informed the senate by letters of several decisions: for example, the restoration of civil rights for Nero's victims (Cass. Dio 66.9.1).

116. Millar 2000. 
of the world that must be carefully weighed in order that it may be brought to the attention of a most illustrious prince in the proper order." 117 The issue is to estimate the efficiency of each means of transmission-correspondence, displaying, and copying.

The main problem of correspondence was slowness, linked to the weakness of ancient technology, but also to the numerous imperial travels (how was it possible to know where the Emperor stayed?), and to the surface of the empire: F. Millar has calculated that when Pliny the Younger wrote his letter 90 to Trajan, the emperor was at 2400 kilometers' distance from him. And according to R. DuncanJones' estimation, ${ }^{118}$ it could take four months to send imperial edicts from the East to Africa, one month from Illyricum to Rome, and the announcement of the emperor's death could take two months to travel from Rome to Egypt and even more if the emperor died in a province. Progress in navigation brought the provinces closer, and Pliny the Elder could list the exploits: only seven days between Sicily and Alexandria, Ostia and Gades, three days between Narbonensis and Ostia, and two days between Ostia and Africa ... (N.H. 19.1.4). However, communications remained slow, and some historians think that in late antiquity they were even slower. ${ }^{119}$

The second means of transmission was the display (propositio) of documents. ${ }^{120}$ Emperors sometimes gave instructions for display, ${ }^{121}$ but many scholars have questioned the legibility of these texts. The answer is double: first, it is necessary to distinguish between permanent texts (like laws), display of which was probably more symbolic than efficient, and temporary texts, like edicts or rescripts, which had to be read; and then to record the measures which were taken over the centuries to ameliorate the transmission of public decisions, such as the practice of recitatio or the obligation of the trinundinum for the laws, ${ }^{122}$ the necessity claimed in many texts to display the inscriptions in a frequented place,

117. Sen. Ad Polyb. 6.5 (Polybius was a studiis and a libellis); cf. Stat. Silv. 5.1.75-100, especially lines 86-88: "To send far and wide into the great world the commands of the Roman prince, to handle all the powers and modes of empire, to learn what laurelled message comes from the north, what news from wandering Euphrates...."

118. Duncan-Jones 1990: 7-29.

119. Brown 1992: 12; cf. Tangheroni 1992: 319.

120. Some documents emphasize the requirement that they be displayed, e.g., Augustus' edicts at Cyrena (FIRA I, 68) and Alexander Severus' edict in 222 about the payment of aureum coronarium (P. Fay. 20 = Hunt and Edgar 1932-1934: 216). Others were only to be read out (for example Claudius' letter to the Alexandrians was posted only on the prefect of Egypt's initiative [Corp. Pap. Iud. 153]) or immediately registered in the archives of the local city (e.g. Octavius' letter about Seleukos of Rhosos was sent to the council and the people of Rhosos in order for them to be informed and to archive the letter [FIRA I, 55.1.7: eis ta dâmosia grammata]; but the letter was posted probably by Seleukos himself for auto-representative purpose, as W. Eck has shown [Eck 1998: 357]).

121. Cf. FIRA I, 73: at the end of his edict on the physicians and professors' privileges, Vespasian added a subscription in which he ordered the edict to be displayed on album (other examples in Ando 2000: 110).

122. Macrob. Sat. 1.16.34-35. 
to engrave them in big letters, to choose the right language according to the region. These various requirements are listed in a text concerning judiciary documents:

By "public notice" is meant a notice in writing, clearly visible and easily read, in the open, for example in front of the shop or the place of business, not hidden away but on display. Should the notice be in Greek or in Latin? It depends on the locality; no one should be able to claim that he did not know what the notice said. Certainly, if the notice was posted openly and was widely read, no one will be heard to say that he did not see it or know what is said. ${ }^{123}$

These measures show how efficient and useful the displays were, as is also shown by the letter sent by Claudius to the Alexandrians and to the Jews of Alexandria and published by the prefect of Egypt because "the city being so big, it was not possible for all the people to be present when the letter was read out." 124 By posting, people could be informed and make copies of a decision (as attested for the imperial answers to petitions) and the practitioners (lawyers especially) could know the judgments. ${ }^{125}$ The story told by Suetonius about Caligula, who, being pressured by the people, ordered a fiscal reform displayed but in small letters in an isolated place in order that "nobody could copy it," confirms again a contrario the regularity of this practice. ${ }^{126}$

The system had its limits. As W. Eck has pointed out in his analysis of the S.C. on Germanicus' honors and the S.C. on Piso's trial, the care taken for the diffusion of information varied depending on whether it concerned Rome, Italy, or the provinces: ${ }^{127}$ the imperial power did not control the network of information outside Rome. The initiative was left to "the magistrates and legates of municipia and coloniae," to the governors, ${ }^{128}$ sometimes to the provincial assemblies. ${ }^{129}$ In

123. Trans. A. Watson = Dig. 14.3.11.3 (Ulpian 28 ad Ed.): Proscribere palam sic accipimus claris litteris, unde de plano recte legi possit, ante tabernam scilicet vel ante eorum locum in quo negotio exercetur, non in loco remoto, sed in evidenti. Litteris utrum Graecis an Latinis? puto secundum loci condicionem, ne quis causari possit ignorantiam litterarum. Certe si quis dicat ignorasse se litteras vel non observasse quod propositum erat, cum multi legerent cumque palam esset propositum, non audietur. On the punishment of one who has damaged a public display, cf. Dig. 2.1.7 pr. (Ulpian 3 ad Ed.): si quis id, quod iurisdictionis perpetuae causa, non quod prout res incidit, in albo, vel in charta vel in alia materia propositum erit, dolo malo corruperit: datur in eum quinquentorum [aureorum] <milium sestertium > iudicium, quod populare est.

124. Corp. Pap. Iud. 153.

125. As was probably the case for Septimius Severus and Caracalla's rescripts (apokrimata) in 200 at Alexandria (P. Columbia 123; Schiller 1954). On these texts, cf. Coriat 1997: 123 n.99.

126. Suet. Cal. 41: "These taxes being imposed (vectigalibus indictis), but the act by which they were levied never submitted to public inspection (nеque propositis), great grievances were experienced from the want of sufficient knowledge of the law. At length, on the urgent demands of the Roman people, he published the law, but it was written in a very small hand, and posted up in a corner, so that no one could make a copy of it." Cf. Cass. Dio 59.28.11; Plin. Pan. 2 (10) 3.3-4.

127. Eck 1996: 352 n.102 and Eck et al. 1996: 208ff.

128. Tabula Siarensis II b = AE 1984: 143 .

129. As under the republic: cf. Sherk RDGE $52=R G E 77$. 
the Roman empire there existed a great diversity of practices and mediations for the diffusion of decisions. Such a system does not help us to estimate the efficiency of the transmission, nor to understand how local decisions were transmitted from one province to another. We have to suppose the existence of private or professional networks of transmission, especially for judicial decisions. But the modalities of that kind of transmission are not clear. ${ }^{130}$

For the third means of communication, the issue was approximately the same. We know that the Roman archives (aerarium, imperial commentarii, fiscus) could give copies of documents to those who requested them. ${ }^{131}$ The jurist Paul confirms this point. ${ }^{132}$

The imperial treasury itself ... issues copies of its own records, on the condition that the person who has a right to take the copy does not make use of these records either against (the imperial treasury) itself or against the state.

Further testimony is supplied by the ritual formula descriptum et recognitum ex ... ("copied and authenticated from") found in many epigraphic documents, ${ }^{133}$ and by indications (date, page, name of register, etc.) which, reported on the copies, authenticated them. However, no general regulation on the topic is attested. We can only say that once the period of display ended, individuals or communities could ask for a copy of a decision, which was probably made at their own expense: this is one of the hypotheses made about the military diplomas which, from the time of Claudius, attested the concession of citizenship to the veterans of the Roman army. As for the replies to petition, we do not know exactly how they were sent. Three means of transmission

130. See Galsterer 1986.

131. The evidence about the imperial commentarii is however scant. See the fragment of an inscription of Enez (Ainos) in Thrace: descr]iptum et recognit[um-ex commen]tari(i)s Lu[ci(i) Septimi(i) Severi Pii Per]tinacis ... ; there followed the names of Caracalla and Geta (AE 1986: 221), quoted by Hauken 1998.

132. Dig. 49.14.45.5-6 (Paulus Sent. 5): Neque instrumenta neque acta a quoquam adversus fiscum edi oportet. Ipse autem fiscus actorum suorum exempla hac condicione edit, ut is, cui describendi fit potestas, adversus se vel rem publicam his actis ne utatur: de quo cavere compellitur, $u t$, si usus is contra interdictum fuerit, causa cadat.

133. This formula is that of the legalized copies, whether they were issued from the center or from the periphery, whether the document was registered in the archives or displayed. The word exemplum (in Greek, antigraphon) also sometimes indicates the official copies in public archives (cf. Octavius' letter to Plarasa Aphrodisias, where, in 20 B.C., the triumvir sends documents to the city copied from the Roman archives: FIRA I, $38=R D G E 28$ ). But, in inscriptions, exemplum or exemplar most often indicates the non-authenticated copy of an original document: see for example the inscription of the Saltus Burunitanus (FIRA I, 103; cf. Hauken 1998: 27-28 n.130). Hadrian's letter de bonorum possessione liberis militum danda, lines 1-9 (BGU I, $140=$ FIRA I, 78); Septimius Severus and Caracalla's edict de longae possessionis praescriptione (BGU I, $267=$ FIRA I, 84), copied in Alexandria (line 12), and all their apokrimata from P. Col. 123 as their praescriptio indicates: antigrapha apokrimaton <pro>thenton en tè stoa tou gumnasiou; other examples in Feissel and Gascou 1995. 
are attested, but their chronology is not well established: replies may be sent through a provincial governor, ${ }^{134}$ directly to the petitioner, ${ }^{135}$ or they may be posted in order to make copying possible ${ }^{136}$ - a mode of communication that was in part passive and perhaps, as some historians have supposed, not very efficient. ${ }^{137}$

It can be said, then, that emperors increased their written communication, but did not always control its diffusion. Regardless, the emperor's image was increasingly linked to his written activity. According to Suetonius, Vespasian admitted his amici only after having read his correspondence and the libelli of

134. Cf. Plin. Ep. 10.107 (108), Trajan's letter: "I have read the petition (libellum) of P. Attius Aquila, centurion of the sixth equestrian cohort, which you sent to me; and in compliance with his request, I have conferred upon his daughter the freedom of the city of Rome. I send you at the same time the patent (libellum rescripti), which you will deliver to him." On the governor's role in the transmission of petitions and of imperial answers, see Burton 1976: $76 \mathrm{ff}$; and also Brunt 1961 and Oliver 1979.

135. Confirmed at the end of the second century by Commodus' answer to the coloni's petition of the Saltus Burunitanus (CIL VIII, 10570 and $14464=$ FIRA I, 103): the expression subscriptionem quam ad libellum suum datam Lurius Lucullus [accepit] (IV, 13-15) shows that the coloni received the petition directly (Nörr 1981: 18).

136. Once the document was no longer posted, could the people ask for a copy? According to Williams (1980: 294), no. But the Smyrnan inscription that relates a demand made by Sextilius Acutianus, on behalf of his citizens, to Antoninus in order to obtain a copy of a constitution of Hadrian, proves the contrary. Antoninus gave his agreement; the rescript was transmitted to the a commentariis who himself asked two scribes to copy the document: Stasime, Dapeni, edite, ex forma sententiam vel constitutionem (CIL III, $411=$ FIRA I, 82). According to N. Purcell (Purcell 1986), the fact that the authorization was engraved proves that it was difficult to have access to the imperial records. But there is other evidence that the access to the tabularium principis was possible (see above, n.96); moreover the Smyrnan inscription proves only that to copy was considered a privilege not a right. Difficulty in gaining access to the imperial commentarii is easy to understand on the model of the magistrates' commentarii: the latter were not easily accessible because they were active records and not "dead registers," like those of laws and S.C., as suggested by J.-L. Mourgues (Mourgues 1998).

137. Were these two last procedures successive or simultaneous? If propositio is the most frequently attested, the notion itself is not absolutely clear, as is shown by the inscription of Skaptopara, a dossier which contains the petition of villagers brought by one of them, Aurelius Pyrrus, to Gordian III (lines 6-7) and the answer of the emperor. The document begins, in lines 2-7, with the formula of authentication: date, then descriptum $\langle e>t$ reco $<g>$ nitum factum $<e>x<$ l $>$ ibro $<$ l>ibellorum rescript $<$ o $>$ rum a domino n(ostro) imp(eratore) $C a<e>s$ (are) $M$ (arco) Antonio Gordiano Pio Felice Aug(usto) $<e>t$ propo $<s>$ it $<o>$ rum $<R>$ oma $<e>$ in portic $<u>$ $<$ th $>$ ermarum Trai $<a>n a r<u>m$ in $v e<r>b a<q($ uae) $>$ i(nfra) s(cripta) $s$ (unt) (CIL III, 12336 $=A E$ 1994, $1552=$ FIRA I, $106=$ IGBulg. IV, 2236). Everybody agrees today that the text is an authentic copy, but the issue is to know where the copy is coming from: a posting or a register? The answer is different according to the sense which is given to the word proponere: does it mean "to post," as most scholars think, or "to put at anybody's disposal in a public archive" (according to D'Ors 1979: 118)? W. Williams, who supports the first hypothesis, has underlined that liber or teuchos can define a collection of petitions, stuck together before being displayed, and not necessarily a register. For D. Nörr (Nörr 1981: n.134), the document was posted but the original was registered in the archives. For a summary of all these debates, see now Hauken 1998: 305 n. 130. 
his ministers. ${ }^{138}$ According to the Historia Augusta, Marcus Aurelius answered petitions even during circus games. ${ }^{139}$ The development of writing was linked to the centralization of the empire and to the capitalization of Rome, as indicated in the biography of Antoninus: "he was regarded with immense respect by all nations since, making residence in the city as he did, for the purpose of being in a central location, he was able to receive messages from every quarter with equal speed." ${ }^{140}$ In his praise of Rome Aelius Aristides also expresses this idea:

If the governor should have even some slight doubt whether certain claims are valid in connection with either public or private lawsuits and petitions from the governed, they straightway send to him with a request for instructions what to do, and they wait until he renders a reply, like a chorus waiting for its trainer. Therefore, he has no need to wear himself out traveling around the whole empire nor, by appearing personally, now among some, then among others, to make sure of each point when he has the time to tread their soil. It is very easy for him to stay where he is and manage the entire civilized world by letters, which arrive almost as soon as they are written, as if they were carried by winged messengers."

Regarding Rome, 32-33, trans. J. Olliver

This link between centralization and government by writing was soon to be transformed. In the beginning of the third century Herodian wrote that where the emperor was, here was Rome. ${ }^{141}$ In both cases, however, it was the same idea: that of a center to which documents moved with haste. Writing had become a primary means of imperial government. Such a development could not be without effect. In fact, it modified the emperor's role and the nature of political society.

\section{THE IMPACT OF WRITING}

The effects of this reliance on writing are well known: first, the reinforcement of the imperial function and specially of the imperial legislative role ${ }^{142}$ then, the idea that the emperor was the only person who could answer all questions, and arbitrate any juridical or judicial problem. In the case of rescripts, the imperial document itself appeared as a protection; and imperial intervention seemed to be a means to get justice against possessores (as it is in the petition of the coloni of Saltus Burunitanus to Commodus ${ }^{143}$ ) or against the imperial personnel (the petition

138. Suet. Vesp. 21: in principatu maturius semper ac de nocte vigilabat; dein perlectis epistulis officiorumque omnium breviarium, amicos admittebat.

139. SHA M. Ant. 15.1. See also Suet. Aug. 45.1, according to whom Caesar, because he read his libelli and his epistulae before the beginning of a game, was reprimanded by the people.

140. SHA Ant. Pius 7.12; the same idea in Amm. Marc. 15.1.2.

141. Herodian 1.6.5.

142. See Coriat 1997; Honoré 2002: 152-53 also shows the changing status of the imperial constitutions, especially vis à vis jurisprudence.

143. CIL VIII, 10570 and $14464=$ FIRA I, 103. 
of Scaptopara is a prayer to the emperor to prohibit some requisitions ${ }^{144}$ ) or even against the governor (we can refer to a letter of Gordian III to Aphrodisias ${ }^{145}$ ). In this way, as Clifford Ando has shown, provincials clearly understood that the emperor was their benefactor and Rome their patria iuris. ${ }^{146}$ But let us pay more attention to the style of communication, which gave a visible, albeit non-explicit message.

It has been often emphasized that at the beginning of the Principate, princes adopted the brief republican style; but the more absolute their power became, the more the imperial orders were free from popular control and became a source of law, the more they achieved a grandiloquent and rhetorical style, giving a more and more important place to the exposé of motivations, as we can see from Diocletian's public documents or from Julian's Letters. ${ }^{147}$ What was this absolute power which sought to persuade or justify itself?

Peter Brown has recorded the role of persuasion in the relations between governing and governed and has shown that this persuasion did not aim only at flattering or deceiving, but also at getting consensus. ${ }^{148}$ In fact, this message was well understood. Provincials not only used the written medium offered by emperors, but they also imitated their style: petitions repeated the same models, the same themes as the edicts. ${ }^{49}$ That was precisely ideology, that is to say shared opinions. What people really thought doesn't interest us and we will never know; the main thing is that they shared the same vocabulary, the same style. Rhetoric standardized the relation in time and space and created the appearance of a cultural community where even self-censorship took the name of consensus. ${ }^{150}$

The use of persuasion sent another message: that recipients were rational men. By rational men, I mean not men of reason, but, following the etymological sense of ratio, men who calculate, who know how to negotiate everything. The emperor spoke in a juridical manner, but at the same time, he signified that all was negotiable. And in fact it was. Petitions and responses show this: individuals and emperors negotiated a privilege, a beneficium, an office. In this way petitions and responses, as well as the style of emperors' writings, had a great importance as an indication of the emperor's exact place in the political system. With this special kind of communication, the emperors created a specific field, which can be called metalegal, from which derived his auctoritas and his legitimacy. And the principal effect of this creation was to transform the nature of respublica.

144. CIL III, $12336=$ AE 1994, $1552=$ FIRA I, $106=$ IGBulg. IV, 2236 .

145. Reynolds 1982: 131 nos. 20-21-22.

146. Ando 2000.

147. Volterra 1971: 821-1097. On Diocletian, cf. Collatio 6.4 (quoted in Volterra 1971: 102829); for Julian, cf. Ep. 25b (ed. Bidez 75b); compare with CTh 13.3.4.

148. Brown 1992; Benner 1975: 176 ff. See also Fronto (ad Ver. 2.1.9): Imperium non potestatis tantum modo vocabulum sed etiam orationis est.

149. Cf. Hauken 1998: 267-68, 149ff.

150. Wallace-Hadrill 1982. 
From the third century, respublica was no longer res populi; it no longer referred to a populus understood as a political entity, ${ }^{151}$ as in the time of the republic and at the beginning of the empire, at least in the juridical sources. ${ }^{152}$ Respublica was now seen as a juxtaposition of individuals linked to the prince by parallel links and parallel material advantages. This new definition appears in a panegyric of Constantinius, precisely in connection with imperial beneficia:

Praetereo privatim reddita omnibus patrimonia quos illa monstrosa labes extorres domo fecerat; praetereo, inquam, quia vix sufficit oratio facta publicitus explicare. Quamquam cum ex singulis sit coagmentata res publica, et quidquid in eam confertur ad omnes pro portione permanat et vicissim necesse est, quod singillatim omnes adipiscuntur, in commune rei publicae redundare.

Pan. Const. 10[4]. 33.7

I won't say a word about the estates that you gave back to those who had been exiled by this plague; I won't, I repeat, because a speech would not be sufficient to expose what you have done for the general interest. However, because a State is an assemblage of individuals, what is done for it is useful proportionately for all, and conversely, what each of them personally has obtained necessarily reflects on the entire community.

Not only is the notion of respublica completely changed, but also that of utilitas communis: during the republic it had been the supreme value under which all particular interests had to be subsumed; now it was linked with particular interests.

So, we could say, it was not really the concentration of powers that had transformed the notion of respublica, and the nature of politics, but the increase of written communication. While the town-crier's voice applied to all the citizens in a public space, and in that way, as Aristotle says, ${ }^{153}$ constituted or reinforced the community, written communication that applied to individuals who claimed particular rights dissolved it. The greatest effect of the change is that legitimacy itself had to be continually questioned and, above all, continually renewed by proclamations, by benefactions, by written communication. This problem of legitimacy, which arose at the end of the republic, was one of the most important of the imperial period. Written communication was one of the means used by emperors to legitimate their power. To govern, said Hobbes, is to persuade, that is, to communicate. This definition, which gives to negotiation a central place in politics, applies perfectly to imperial times.

My purpose has been to give a general survey of the effects of movement on social, political, and intellectual structures by exploring some of its most important aspects: translation, migration, and communication. Movement changes the role 
of the state as well as relations between individuals and states, augments the use of writing, transforms identities, and gives impulse to internal or international regulations. It has effects in all fields, administrative, judicial, and political.

But the implications of movement are not only pragmatic: they are also formal. In fact, by changing the relation to space and time, movement and writing also influence forms of thinking and organizing; they influence thought itself. It is through this double aspect, pragmatic and formal, that the history of movement becomes part of intellectual history.

University of Southern California moatti@usc.edu

\section{BIBLIOGRAPHY}

Adams, J. N. 2003. Bilingualism and Latin Language. Cambridge.

Ando, C. 2000. Imperial Ideology and Provincial Loyalty in the Roman Empire. Berkeley.

Andreotti, R. 1969. "Su alcuni problemi del rapporto fra politica, sicurezza e controllo del commercio nell' impero romano." RIDA 16: 215-57.

Assman, J. 1997. Moses the Egyptian. The Memory of Egypt in Western Monotheism. Cambridge, Mass.

Baccari, M. Pia. 1996. Cittadini, popoli e comunione nella legislazione dei secoli IV-VI. Turin.

Balsdon, J. P. V. D. 1979. Romans and Aliens. London.

Barnes, J. 1997. "Roman Aristotle.” In J. Barnes and M. Griffin, eds., Philosophia Togata II, 1- 69. Oxford.

Behr, C. A. 1981. P. Aelius Aristides, The Complete Works. Vol. 2. Leiden.

Benjamin, W. 1991. Écrits français. Paris.

Benner, M. 1975. The Emperor Says: Studies in the Rhetorical Style in Edicts of the Early Empire. Göteburg.

Benveniste, E. 1933. "Notes étrusques. I: La tablette d'ivoire de Carthage." $S E$ 7: 245-49.

Bettini, M. 2000. Le orecchie di Hermes. Studi di antropologia e di letteratura classiche. Rome and Bari.

Bieber, M. 1977. Ancient Copies. New York.

Black, E. W. 1995. Cursus Publicus: The Infrastructure of Government in Roman Britain. $B A R-B S$ 241. Oxford.

Bloomer, W. M. 1997. Latinity and Literary Society at Rome. Philadelphia.

Bove, L. 1984. "Le tabulae ceratae." Atti del XVII Congr. intern. di papirologia. Vol. IIII, 1189-1200. Naples.

Bowersock, G. W. 1965. Augustus and the Greek World. Oxford.

Boyancé, P. 1976. "Les implications philosophiques des recherches de Varron sur la religion romaine." Atti Congr. studi varroniani, 137-61.

Brague, R. 1992. Europe, la voie romaine. Paris.

Bresson, A. 2004. "Les accords romano-carthaginois." In Moatti 2004, 649-76.

Brown, P. 1992. Power and Persuasion in Late Antiquity Towards a Christian Empire. London. 
Brunt, P. 1961. "Charges of Provincial Maladministration Under the Early Principate." Historia 10: 189-227.

Burton, G. P. 1976. "The Issuing of Mandata to Proconsuls and a New Inscription from Cos." ZPE 21: 63-68.

Camodeca, G. 1993. "Novità sulle tavolette cerate de Pompei ad Ercolano." In Ercolano 1738-1988. 250 anni di ricerca archeologica: Atti Conv. intern. Ravello-ErcolanoNapoli-Pompei, 30 oct.-5 nov. 1988, 521-27. Rome.

Castello, C. 1951. L'acquisito della cittadinanza e i suoi riflessi familiari nel diritto romano. Milan.

Charles, R. H., ed. 1963. The Letter of Aristeas. In The Apocrypha and Pseudopigrapha of the Old Testament, vol. 2, 82-122. Oxford.

Chassignet, M. 1996. L'Annalistique romaine, I: Les Annales des pontifes et l'annalistique ancienne. Paris.

Coriat, J.-P. 1997. Le prince législateur, La technique législative des Sévères et les méthodes de création du droit impérial à la fin du principat. Rome.

Courcelle, P. 1969. Late Latin Writers and Their Greek Sources. Trans. H. E. Wedeck. Cambridge, Mass.

Crawford, M. 1978. "Greek Intellectuals and the Roman Aristocracy in the First Century B.C.” In P. D. A. Garnsey and C. R. Whittaker, eds., Imperalism in the Ancient World, 193-207. Cambridge.

Desbordes, F. 1991. "Latinitas: Constitution et évolution d'un modèle de l'identité linguistique." In S. Saïd, ed., Hellenismos. Quelques jalons pour une histoire de l'identité grecque. Actes du colloque de Strasbourg (25-27 oct. 1989), 33-44. Leiden andNew York.

Diagne, S. B. 2001. Islam et société ouverte. La fidélité et le mouvement dans la pensée de Mudhammad Iqbal. Paris.

D’Ors, A., and F. Martin. 1979. "Propositio libellorum." AJPh 1979: 111-24.

Dubois, J.-D., et al., eds. 1994. Oeuvres Complètes / Justin Martyr. Paris.

Dubuisson, M. 1982. "Y a-t-il eu une politique linguistique romaine?" Ktèma 7: 187205.

. 1985. Le latin de Polybe. Les implications historiques d'un cas de bilinguisme. Paris.

Duncan-Jones, R. 1990. Structure and Scale in the Roman Economy. Cambridge.

Eck, W. 1996. "I sistemi di trasmissione delle communicazioni d'officio in età altoimperiale." In M. Pani, ed., Epigrafia e territorio. Politica e società, Temi di antichità romane, IV, 331-52. Bari.

- 1998. "Documenti amministrativi: Pubblicazione e mezzo di autorappresentazione." In Epigrafia romana in area adriatica (Macerata 10-11 nov. 1995), 343-66. Rome.

- 1999. L'Italia nell'Impero romano: Stato e amministrazione in epoca imperiale. Documenti e Studi 25. Italian trans. of Die Staatliche Organisation Italiens in der hohen Kaiserzeit (Munich, 1979). Bari.

Eck, W., A. Caballos, and F. Fernandez. 1996. Das Senatus Consultum de Cn. Pisone Patre. Munich.

Elsner, J. 2001. "Describing the Self in the Language of the Other: Pseudo (?) Lucian at the Temple of Hierapolis." In S. Goldhill, ed., Being Greek under Rome, 123-54. Cambridge.

Escurac, G.P. 1988. "Origine et résidence dans le monde du commerce sous le HautEmpire." Ktèma 13: 57-68. 
Feissel, D., and J. Gascou. 1995. "Documents d'archives romains inédits du moyen Euphrate (IIIe s. après J.-C.)." Journal des Savants, Janv.-Juin: 65-119.

Fögen, T. 2000. Patrii sermonis egestas. Einstellungen lateinischer Autoren zu ihrer Muttersprache. München and Leipzig.

Foucault, M. 1972. Archaeology of Knowledge. Trans. A. M. Sheridan Smith. New York. Frontisi, Fr. 1991. Le dieu-masque. Paris.

Galsterer, H. 1986. "Roman Law in the Provinces. Some Problems of Transmission." In M. Crawford, ed., L'impero romano e le strutture economiche e sociali delle province, 13-27. Côme.

Gardner, J. 1986. "Proofs of Status in the Roman World." BICS 33: 1-14.

Gaudemet, J. 1958. "L'étranger au Bas-Empire." In L'étranger, Recueils de la société J. Bodin, 9: 209-35.

Gauthier, P. 1972. Symbola. Les étrangers et la justice dans les cités grecques. Nancy.

Gazda, E. K. 1995. "Roman Sculpture and the Ethos of Emulation: Reconsidering Repetition." HSCPh 97: 21-156.

- 2002. The Ancient Art of Emulation: Studies in Artistic Originality and Tradition from the Present to Classical Antiquity. Ann Arbor.

Ginzburg, C. 2000 [1986]. "Spie: Radice di un paradigmo indiziario.” In C. Ginzburg, Miti, emblemi, spie: Morfologia e storia, 158-209. Turin.

Girard, P. F., and F. Senn. 1977. Les lois des Romains. Naples.

Goffart, W. 1980. Barbarians and Romans: The Techniques of Accommodation, AD 418-584. Princeton.

Gras, M. 1985. Trafics tyrrhéniens archaïques. BÉFAR, 258. Rome.

Grelle, F. 1993. "La forma dell'Impero." In A. Momigliano and A. Schiavone, eds., Storia di Roma, vol. 3.1: L'Età tardoantica: Crisi e trasformazioni, 69-82. Rome.

Habinek, T. 1998. The Politics of Latin Literature. Princeton.

Haley, E. W. 1991. Migration and Economy in Roman Imperial Spain. Barcelona.

Hasebroek, J. 1921. Das Signalement in den Papyrusurkunden. Papyrusinstitut Heidelberg, Schrift 3. Berlin.

Hauken, T. 1998. Petition and Response. An Epigraphic Study of Petitions to Roman Emperors, 181-249. Monographs from the Norwegian Institute at Athens, vol. 2. Bergen.

Hölscher, T. 1987. Römische Bildsprache als semantisches System. Heidelberg.

Honoré, T. 2002. Ulpian, Pioneer of Human Rights. Oxford.

Hopkins, K. 1991. "Conquest by Book." In Literacy in the Roman World. JRA, suppl. series n. 3: 133-58. Ann Arbor.

Horden, P., and N. Purcell. 2000. The Corrupting Sea: A Study of Mediterranean History. Oxford.

Hunt, A. S., and C. C. Edgar. 1932-1934. Select Papyri. 2 vols. Cambridge, Mass.

Kaimio, J. 1979. The Romans and the Greek Language. Helsinki.

La Penna, A. 1976. "Alcuni concetti di base di Varrone sulla storia romana, II." Atti Congr. studi varroniani, 397-407. Rieti.

La Piana, G. 1927. "Foreign Groups in Rome." HThR 20: 183-403.

Lukaszewicz, A. 1990. "Quelques remarques sur l'expulsion des Aigyptoi d'Alexandrie.” In G. Nenci and G. Thür, eds., Symposion 1988, Vorträge zur grieschichen und hellenistischen Rechtsgeschichte. Communicazioni sul diritto greco ed ellenistico (Siena-Pisa, 6-8 giugno 1988), 341-47. Cologne and Vienna.

MacCrum, A., and A. G. Woodhead. 1966. Select Documents of the Principate of the Flavian Emperors, Including the Year of Revolution (68-96 A.D.). Cambridge.

MacMullen, R. 1990. Changes in the Roman Empire. Princeton. 
Marichal, R. 1992. Les Ostraca de Bu Njem. Tripoli.

Marotta, V. 1991. Mandata principum. Turin.

. 1999. "Liturgia del potere. Documenti di nomina e cerimonie di investitura fra principato e tardo impero romano." Ostraka Ann. VIII, 1: 145-220.

Mazzarino, S. 1951. Aspetti sociali del quarto secolo. Ricerche di storia tardo-romana. Rome.

Meyer, E. A. 2004. Legitimacy and Law in the Roman World. Cambridge.

Millar, F. 1977. The Emperor in the Roman World. London.

— 1984. "State and Subject. The Impact of Monarchy." In F. Millar and E. Segal, eds., Caesar Augustus. Seven Aspects, 37-60. Oxford.

— 2000. “Trajan, Government by Correspondence.” In J. Gonzalez, ed., Trajano Emperador de Roma, 363-88. Rome.

Mitchell, S. 1976. "Requisitioned Transport in the Roman Empire. A New Inscription from Pisidia." JRS 66: 106-31.

Moatti, C. 1997. La raison de Rome. Naissance de l'esprit critique à l'époque républicaine (IIe -Ier s. avant J.-C.). Paris.

- 2000. "Le contrôle de la mobilité des personnes dans le monde romain." MEFRA 122, 2: 925-58.

. 2001. "Respublica et droit à la fin de la république romaine." MEFRM 113, 2: 811-37.

. 2003. "La construction du patrimoine culturel à Rome à la fin de la république et au début du principat." In M. Citroni, ed., Memoria e identità. La cultura romana costruisce la sua imagine, 81-98. Florence.

— ed. 2004. La mobilité des personnes en Méditerranée. Procédures de contrôle et documents d'identification. Collection de l'École française de Rome, 341. Rome.

Mommsen, T. 1984 [1892]. Droit public romain, I. Paris.

Mourgues, J.-L. 1995. "Écrire en deux langues: Bilinguisme et pratique de chancellerie sous le Haut-Empire romain." DHA 21: 105-29.

_ 1998. "Forme diplomatique et pratique institutionnelle des commentarii Augustorum." In Moatti, C. ed., La mémoire perdue. Recherches sur l'administration romaine. CÉFR 243, 123-98. Rome.

Neri, V. 1998. I marginali nell'occidente tardoantico. Poveri, infames e criminali nella nascente società cristiana. Bari.

Nicolet, C. 1988. L'inventaire du monde. Paris.

Nörr, D. 1981. “Zur Reskriptenpraxis in der Hohen Prinzipatzeit.” ZS 98: 1-46.

Noy, D. 2000. Foreigners at Rome. London.

Oliver, J. H. 1979. " "Greek Applications for Roman Trials." AJPh 100: 543-58.

Opelt, I. 1969. "La coscienza linguistica dei Romani.” A\&R 14 no. 2-3: 21-37.

Paola, L. di. 1999. Viaggi, trasporti e istituzioni. Studi sul cursus publicus. Messine.

Pelletier, A. 1962. Lettre d'Aristée à Philocrate. Paris.

Peter, H. 1967 [1870, 1914]. Historicorum Romanorum Reliquiae. Stuttgart.

Pollini, J. 1987. The Portraiture of Gaius and Lucius Caesar. New York.

- 1999. Review of D. Boschung, Die Bildnisse des Augustus (Berlin, 1993). ArtBull. 81, 4: 723-35.

Powell, J. G. F. 1995. “Cicero's Translations from Greek.” In J. G. F. Powell, ed. Cicero the Philosopher, 273-300. Oxford.

Purcell, N. 1986. " "The Arts of Government.” In J. Boardman, ed., The Oxford History of the Classical World, 560-91. New York.

Rawson, E. 1985. Intellectual Life in the Roman Republic. London.

Reggiani, C. K. 1979. La lettera di Aristea a Filocrate. Rome. 
Reinhold, M. 1971. "Usurpation of Status and Status Symbols in the Roman Empire." Historia 20: 275-302.

Reynolds, J. 1982. Aphrodisias and Rome. London.

Ricci, C. 1994. "Africani a Roma. Testimonianze epigrafiche di età imperiale di personnagi provenienti dal Nordafrica." AntAfr 30: 189-207.

Ricoeur, P. 1985. Temps et récit. III. Le temps raconté. Paris.

Roxan, M. 1981. "The Distribution of Roman Military Diplomas.” EpSt 12: 265-86.

Sachot, M. 1999. L'invention du Christ. Paris.

Scafuro, A. C. 1994. "Witnessing and False Witnessing: Proving Citizenship and Identity in Fourth-Century Athens." In A. L. Boegehold and A. Scafuro, eds., Athenian Identity and Civic Ideology, 156-98. Baltimore and London.

Scardigli, B. 1991. I trattati romano-cartaginesi. Pisa.

Schiller, A. A., and W. L. Westermann. 1954. Apokrimata: Decisions of Septimius Severus on Legal Matters. New York.

Settis, S. 1989. " "Un arte plurale. L'impero romano, i Greci e i posteri." In A. Momigliano and A. Schiavone, eds., Storia di Roma, vol. 4: Caratteri e morfologie, 827-78. Turin.

Sherk, R. K. 1969. Roman Documents From the Greek East. Baltimore.

Sherwin-White, A. N. 1966. The Letters of Pliny: A Historical and Social Commentary. Oxford.

Talbert, B. A. 1984. The Senate of Imperial Rome. Princeton.

Tangheroni, M. 1992. "L'Italia e la navigazione mediterranea dopo la fine dell'Impero d'Occidente." In G. Aujac et al., Optima hereditas: Sapienza giuridica romana e conoscenza dell'ecumene. Milan.

Thomas, Y. 1997. "Fictio legis: L'empire de la fiction romaine et ses limites médiévales." Droits 1997: 17-78.

1998. Origine et commune patrie. Rome.

Traina, A. 1970. Vortit barbare. Le traduzioni poetiche da Livio Andronico a Cicerone. Rome.

- 1989. "Le traduzioni." In G. Cavallo, P. Fedeli, and A. Giardina, eds., Lo spazio letterario di Roma antica, II: La circolazione del testo, 93-123. Rome.

Vernant, J.-P. 1988. L'individu, la mort, l'amour. Paris.

Volterra, E. 1971. "Il problema del teste delle costituzioni imperiali." In La critica del testo. Atti del secondo congresso internazionale della societé italiana di storia del diritto, II, 821-1097. Florence.

Wallace-Hadrill, A. 1982. "Civilis Princeps: Between Citizen and King." JRS 72: 32-48.

- 1998. "To Be Roman, Go Greek. Thoughts on Hellenization at Rome." In M. Austin, ed., Modus Operandi. Essays in Honour of G. Rickman, 79-91. London.

Walzer, M. 1983. Spheres of Justice. A Defense of Pluralism and Equality. New York.

Weiss, P. 1997. "Neue Militärdiplome." ZPE 117: 227-68.

Whittaker, D. 1989. Les frontières de l'Empire romain. Paris and Besançon.

Williams, W. 1980. “The Publication of Imperial Subscripts.” ZPE 40: 283-94.

Young, G. K. 2001. Rome's Eastern Trade. International Commerce and Imperial Policy $31 B C-A D$ 305. New York and London.

Zanker, P. 1983. Provinzielle Kaiserporträts. Munich. 